\title{
Minority rights, integration and education in the Western Balkans
}

\author{
Elizabeth CRAig ${ }^{1}$ \\ Sussex Law School
}

\begin{abstract}
Using the lenses of minority rights and developments in education in the Western Balkans, this article analyses the adaptability of the European minority protection framework and identifies ongoing challenges in relation to its implementation. It focuses in particular on the balance between the accommodation of minority education rights and integration, arguing that there is an inherent flexibility within the European minority protection framework that has been used to good effect. It claims that a shift towards a more integrated approach to education in the Western Balkans was a necessity and one that strengthens rather than weakens the European minority protection framework. The argument is developed through consideration of the case studies of Bosnia and Herzegovina and the Former Yugoslav Republic of Macedonia, where ongoing challenges remain.
\end{abstract}

\section{Introduction}

$\mathrm{I}$ t has been over a quarter of a century since the re-emergence of minority rights as a response to the resurgence of nationalism and ethnic conflict in Europe. This culminated in the adoption of the Council of Europe's Framework Convention for the Protection of National Minorities (FCPNM) ${ }^{2}$ However, minority rights now appear to be in decline with a period of rapid evolution in the 1990s followed by a period of stabilisation and consolidation and, more recently, 'overall fatigue'. ${ }^{3}$ Using the lenses of minority rights and developments in education in the Western Balkans, the article analyses the adaptability of the minority protection framework and identifies ongoing challenges in relation to its implementation. It focuses in particular on the balance between the accommodation of minority education rights and integration, arguing that there is an inherent flexibility within the European minority protection framework that can be used to particular effect where there remains a risk of conflict between groups. The phenomenon of 'parallel societies' is

1 With particular thanks to Dr Stephanie Berry and Dr Charlotte Skeet and an anonymous reviewer for their helpful feedback on earlier drafts of this article. All errors are of course my own.

2 Council of Europe Treaty No 157, 1 February 1995.

3 Francesco Palermo, 'Addressing Contemporary Stalemate in the Advancement of Minority Rights: Commentary on Language Rights of Persons belonging to National Minorities' in Tove H Malloy and Ugo Caruso (eds), Minorities, their Rights, and the Monitoring of the European Framework Convention for the Protection of National Minorities: Essays in Honour of Rainer Hofmann (Martinus Nijhoff 2013) 124. 
well known and is a particular danger in societies emerging from conflict. ${ }^{4}$ It has also been argued that there is often greater resistance to minority rights in contexts where ethnic relations are 'securitised', as in the Western Balkans. ${ }^{5}$ The drafters of the FCPNM were particularly mindful of developments in the former Yugoslavia, with events in Central and Eastern Europe after 1989 very much in the forefront of discussions on the 'new' Europe. ${ }^{6}$ Its application in that context therefore provides a particularly useful focus for discussion of its continued relevance and adaptability. Meanwhile education is considered a crucial lens through which to explore these issues not just because of the prominence of education in the FCPNM itself, but also because of the unique role education plays both as 'an important means for socialization within the state but also a primary instrument for a minority's cultural reproduction'. ${ }^{7}$ Education matters because of the key role that it plays in shaping the future and, as a result, can itself often become the source of political and cultural contestation in post-conflict societies. ${ }^{8}$ However, it can also play a useful role in contributing to the development of a new 'symbolic landscape', which challenges the divisions and narratives of the past. ${ }^{?}$

The first section of the article highlights the prominent role given to education in the FCPNM, and analyses the extent to which the European minority protection framework is sufficiently flexible to serve both accommodationist and integrationist ends. It considers how approaches to integration have evolved over time, arguing that there has been a notable shift towards integration in education in relation to societies where there remains a risk of conflict and simmering tensions between groups. Using Bosnia and Herzegovina $(\mathrm{BiH})$ and the Former Yugoslav Republic of Macedonia (FYROM) as case studies, ${ }^{10}$ the article then evaluates the practical implications of this evolution in approach. These case studies have been chosen as they provide classic examples of 'deeply divided societies', where ethno-cultural and national differences 'are persistent markers of political identity and bases for political mobilisation'11 and where there remains at least a threat of violent conflict. ${ }^{12}$ This was exactly the type of situation that the European minority rights regime was intended to address and these case studies are

4 Will Kymlicka, 'Multiculturalism and Minority Rights: West and East' (2002) 4 Journal on Ethnopolitics and Minority Issues in Europe 1, 12.

5 Ibid.

6 Peter Cumper and Steven Wheatley (eds), Minority Rights in the New' Europe (Martinus Nijhoff 1999).

7 Walter A Kemp, Quiet Diplomacy in Action: The OSCE High Commissioner on National Minorities (Martinus Nijhoff 2001) 123-4.

8 For an overview of how this can play out in relation to education in a post-conflict society, see Laura Lundy, 'Mainstreaming Children's Rights in, to and through Education in a Society Emerging from Conflict' (2006) 14 International Journal of Children's Rights 339. One prominent example in the Western Balkans was the controversy over the establishment of the private University of Tetovo by ethnic Albanians in the FYROM in the 1990s discussed by Steven R Ratner, 'Does International Law Matter in Preventing Ethnic Conflict?' (2000) 32 New York University Journal of International Law and Politics 591.

9 Joanne McEvoy, 'Managing Culture in Post-conflict Societies' (2011) 6 Contemporary Social Science 55; Marc Howard Ross (ed), Culture and Belonging in Divided Societies: Contestation and Symbolic Landscapes (University of Pennsylvania Press 2009).

10 Although there are similar issues around integration in education in Kosovo, it has a different status under the FCPNM - see Agreement related to the Framework Convention for the Protection of National Minorities in Kosovo concluded between the Council of Europe and the UN Interim Administration Mission in Kosovo on 23 August 2004.

11 This is the definition of a divided society used in Sujit Choudhry, Bridging Comparative Politics and Comparative Constitutional Law: Constitutional Design in Divided Societies' in Sujit Choudhry (ed), Constitutional Design for Divided Societies: Integration or Accommodation? (OUP 2008) 5.

12 The term 'deeply divided society' where there is a risk of violent conflict is used by Adrian Guelke, Politics in Deeply Divided Societies (Polity Press 2012) 9. 
used to illustrate the flexibility of the minority protection framework in practice. However, they also highlight ongoing obstacles in relation to implementation. The case studies therefore provide important insights into both the continued relevance of European minority rights standards, as well as ongoing challenges to their realisation. The article adds to the expanding literature on integration and minority rights, ${ }^{13}$ using the example of education in the Western Balkans to defend its use and application in postconflict situations. Whilst Xanthaki has argued the concept of integration is often used to dilute human and minority rights protection, ${ }^{14}$ the argument here is that the shift to greater emphasis on the need for integration in the Western Balkans was a necessity and one that strengthens rather than weakens the European minority protection framework.

\section{The approach to diversity in education under the FCPNM}

Seeking to accommodate minority claims implies searching for a balance between unity and separation, cohesion and respect for diversity. If one opts solely for unity, the risk is assimilation and the disappearance of a minority as a distinct group; if one chooses exclusively diversity, the result can be the cultural 'ghettoization' of a minority group with consequent separation and marginalisation from society. ${ }^{15}$

There has been a strong emphasis in the literature on the advantages of approaches that emphasise accommodation over integration in addressing differences in divided societies and in relation to conflict regulation. ${ }^{16}$ According to McGarry et al, 'accommodation promotes both the public and private maintenance of cultural difference', whereas with integrationist approaches the focus is on the development of 'a common public space'. ${ }^{17}$ Their view is that 'integration' needs to be distinguished from 'assimilation', which aims also at the 'erosion' of differences in the private sphere. ${ }^{18}$ The view of many working in the field of minority rights is that approaches that tolerate differences only in the private sphere are also assimilationist and therefore unacceptable. ${ }^{19}$ Indeed, Hadden's conceptualisation of the term 'integration' is rather different and he argues that the term covers 'structures and policies aimed at securing full recognition of the identity and culture of members of minority communities and their full participation as such in national or regional society or government'. ${ }^{20}$ As alluded to in the quote above, the key for minority rights lawyers is the balance between accommodationist goals, which tend to promote separation and respect for diversity, and a more integrationist approach, which tends to promote unity and social cohesion. For the purposes of this article, a key feature of integration is working towards the goal of developing common public spaces and a shared identity (and not one that reflects only the majority culture or imposed by the

13 E.g. Kristin Henrard, 'Tracing Visions on Integration and/of Minorities: An Analysis of the Supervisory Practice of the FCNM' (2011) 13 International Community Law Review 333; Roberta Medda-Windischer, Old and New Minorities: Reconciling Diversity and Cohesion (Bolzano/Bozen, European Academy 2009); Tom Hadden, 'Integration and Separation: Legal and Political Choices in Implementing Minority Rights' in Nazila Ghanea and Alexandra Xanthaki (eds), Minorities, Peoples and Self-Determination (Brill 2005).

14 Alexandra Xanthaki, 'Against Integration, for Human Rights' (2016) 20 International Journal of Human Rights 815.

15 Medda-Windischer (n 13) 14.

16 Sujit Choudhry (ed), Constitutional Design for Divided Societies: Integration or Accommodation? (OUP 2008). See also McEvoy (n 9).

17 John McGarry, Brendan O'Leary and Richard Simeon, 'Integration or Accommodation? The Enduring Debate in Conflict Regulation' in Choudhry (n 16) 42.

18 Ibid 42-4.

19 Medda-Windischer (n 13) 19.

20 Hadden (n 13) 176. 
state) and a key feature of accommodation is recognition of a range of group identities in the public sphere through separate facilities and institutions.

According to Hadden, an assimilationist approach in the sphere of education might involve the creation of common schools with a prescribed national curriculum. In comparison a more integrationist approach would involve genuinely integrated schools with multicultural curricula either in addition to, or instead of, separate schools (which reflect more of an accommodationist approach). ${ }^{21}$ Writing in 2005, he argues that there is genuine choice for governments under international $\mathrm{law}^{22}$ and concludes that a 'mix of objectives and measures may be best' with how decisions are made being $\mathrm{key}^{23}$ in managing 'swings of the pendulum between assimilation, integration and separation'. 24 The aim of this section is to show how the FCPNM allows for a shifting in the goals and priorities over time and in different contexts, with a clear steer emerging from the international community towards a more integrated approach in societies emerging from conflict. The European Court of Human Rights has been strongly criticised for favouring assimilation over a more robust approach to minority language rights, ${ }^{25}$ and in highlighting the instrumental function of language rather than its role in constituting identities. $^{26}$ The FCPNM was supposed to herald a new approach, with its emphasis on the protection and promotion of minority cultures and identities. It has, however, been criticised for not being sufficiently accommodationist because it does not include rights to autonomy or self-government, with unfavourable comparisons being made with the approach of the international human rights community to the rights of indigenous peoples. ${ }^{27}$ Meanwhile closer examination of the education provisions of the FCPNM also reveals a more nuanced picture, with the vagueness of relevant provisions allowing for considerable flexibility in approach. Education features particularly prominently in the FCPNM, which has three provisions focused on this area and a specific mention also in Article 6.28

It is undoubtedly the case that integration is increasingly being discussed by the Advisory Committee on the Framework Convention (ACFC), which was established to assist in evaluating the measures taken by states, ${ }^{29}$ in a range of different contexts and not just in relation to new minorities and immigrants. ${ }^{30} \mathrm{~A}$ key provision of the FCPNM is Article 5(1), which requires states 'to promote the conditions necessary for persons belonging to national minorities to maintain and develop their culture, and to preserve the essential elements of their identity, namely their religion, language, traditions and cultural

21 Ibid 188.

22 Ibid.

23 See e.g. the requirements in Article 15 FCPNM on effective participation.

24 Hadden (n 13) 190-1.

25 See, in particular, The Belgian Linguistic Case (No 2) (1979-80) 1 EHRR 252, judgment of 23 July 1968.

26 Moria Paz, 'The Tower of Babel: Human Rights and the Paradox of Language' (2014) 25 European Journal of International Law 473.

27 Will Kymlicka, 'The Internationalization of Minority Rights' 6 International Journal of Constitutional Law 1, 3. See also Will Kymlicka, 'The Internationalization of Minority Rights' in Choudhry (n 16).

28 Articles 12-14 are discussed further below. Meanwhile Article 6 provides that: 'The Parties shall encourage a spirit of tolerance and intercultural dialogue and take effective measures to promote mutual respect and understanding and co-operation among all persons living on their territory, irrespective of those persons' ethnic, cultural, linguistic or religious identity, in particular in the fields of education, culture and the media'.

29 Article 26.

30 Merja Pentikeinen, 'Social Integration of Old and New Minorities in Europe in Views of International Expert Bodies Relying on Human Rights: Contextual Balancing and Tailoring' (2015) 14 Journal on Ethnopolitics and Minority Issues in Europe 26, 32-3. 
heritage'. However, Article 5(2) makes it clear that states are to refrain from assimilation of persons belonging to minorities 'against their will' and to protect them 'from any action aimed at such assimilation', stipulating this is '[w]ithout prejudice to measures taken in pursuance of their general integration policy'. Xanthaki has observed that the initiative for discussion of integration often comes from states and can be used as an excuse for assimilation. ${ }^{31}$ It is furthermore also often seen as a one-way process ${ }^{32}$ and as a way of denying equality between groups. ${ }^{33}$ Whilst Xanthaki's focus is primarily on discussions over the integration of migrants, Palermo has observed a similar tendency where there has been a shift from a focus on minority rights towards greater emphasis on social cohesion in post-conflict societies. ${ }^{34} \mathrm{He}$ too notes that this is sometimes done in a way that restricts minority rights, for example, through additional requirements being placed on minorities to show loyalty and knowledge of the official language. ${ }^{35}$ Significantly, he links this trend towards using social cohesion and integration to restrict minority rights to the perception of groups as homogeneous and identities as fixed, not just amongst states but also within the minority rights framework itself. ${ }^{36}$ His analysis therefore suggests the need for greater recognition of the complexity of identities and of multiple and evolving affiliations - an approach we are increasingly seeing in the monitoring work under the FCPNM. ${ }^{37}$ However, as shall be demonstrated, it is also the case that the international community itself has been pushing for greater integration in a range of different contexts.

If it is accepted that approaches which relegate cultural differences to the private sphere are essentially assimilationist, then the extent of the state's duties in relation to the protection and promotion of minority education within the public sphere acquires particular significance. It is generally assumed that human and minority rights instruments promote separate educational facilities over a more integrated approach in the sphere of education. ${ }^{38}$ However, the requirements in relation to the provision of minority language education under Article 14(2) of the FCPNM are not particularly onerous on states, ${ }^{39}$ with no requirement to fund private minority schools ${ }^{40}$ or specific obligations in relation to higher education. ${ }^{41}$ Furthermore the recognition in Article 14(1) of the right of 'every person belonging to a national minority ... . to learn his or her minority language' is qualified in the Explanatory Report with the statement that this 'does not entail any

31 Xanthaki (n 14) 821.

32 Ibid 823.

33 Ibid 827-9.

34 Palermo (n 3) 132.

35 Ibid 132.

36 Ibid.

37 Palermo focuses in particular on the ACFC, Commentary No 3: The Language Rights of Persons Belonging to National Minorities under the Framework Convention, 24 May 2012. However, see also ACFC, Commentary No 4: The Scope of Application of the Framework Convention for the Protection of National Minorities (27 May 2016). This evolving approach is also evident in relation to the principle of selfidentification - see Elizabeth Craig, 'Who Are the Minorities? The Role of the Right to Self-Identify within the European Minority Rights Framework' (2016) 15(2) Journal on Ethnopolitics and Minority Issues in Europe 6-30.

38 Hadden (n 13) 175.

39 Article 14(2): 'In areas inhabited by persons belonging to national minorities traditionally or in substantial numbers, if there is sufficient demand, the Parties shall endeavour to ensure, as far as possible and within the framework of their education systems, that persons belonging to those minorities have adequate opportunities for being taught the minority language or for receiving instruction in this language.'

40 Article 13(2).

41 See Will Kymlicka, Multicultural Odysseys: Navigating the New International Politics of Diversity (OUP 2007) 215. 
financial obligation for the Party concerned'. ${ }^{42}$ However, as shall be seen, this has not prevented the $\mathrm{ACFC}^{43}$ from requiring the development of systems of minority language education provided for and funded by the state. ${ }^{44}$

Meanwhile there are a number of provisions which address wider issues that affect all individuals and groups within society, and not just those belonging to a minority group, and relate to the promotion of unity and social cohesion. ${ }^{45}$ At a very basic level there is first of all the stipulation that states' undertakings in relation to minority language education in Article 14(2) should not thereby prejudice 'the learning of the official language or the teaching in this language'. ${ }^{46}$ The idea that minority and majority identities can co-exist in the public sphere is further reinforced by Article 12, which promotes intercultural as well as multicultural education. Whilst Article 12(3) of the FCPNM deals with the issue of equal opportunities for educational access, Article 12(1) requires states to 'where appropriate, take measures in the fields of education and research to foster knowledge of the culture, history, language and religion of their national minorities and of the majority' (emphasis added). Article 12(2) then addresses the need for 'adequate opportunities' for teacher training and access to textbooks and calls upon states to facilitate contacts amongst those from minority and majority groups. According to the ACFC, Article 12 (along with Article 6) supports 'the core ethos of the Framework Convention as one of intercultural dialogue, integration of minorities in the wider society and social cohesion'. ${ }^{47}$ Its position has consistently been that 'all aspects and elements of education should ensure a climate of tolerance and dialogue'. ${ }^{48}$ Although the undertakings in Article 12 again do not appear particularly onerous, this has not prevented the ACFC from adopting a fairly robust approach, as will be evidenced in later sections of this article. It is also significant that the provisions on education do not stand alone. There are, for example, undertakings in Articles 4-6 on effective equality and nondiscrimination, as well as positive obligations in relation to the maintenance and development of minority cultures and to the promotion of mutual understanding and tolerance. These are considered to form 'a continuum of core obligations' that have informed the ACFC's approach in making recommendations to states. ${ }^{49}$ The balancing of the three aspects is key to the ACFC's work and to its success.

Some of the early criticisms of the FCPNM focused on the lack of definition of the term 'national minority', the vagueness of many of the provisions and the potential for political influence on the monitoring process through the role of the Committee of Ministers. ${ }^{50}$ It is argued here that the flexibility inherent in the FCPNM means that these aspects should now be seen as potential strengths. This will be evidenced through consideration of how the ACFC has approached the balancing of minority rights and integration in the context of $\mathrm{BiH}$ and the FYROM in a way that strengthens rather than

42 Council of Europe, Explanatory Report to the Framework Convention for the Protection of National Minorities (1995) para 73.

43 Article 26.

44 See also ACFC, Commentary No 1: Commentary on Education under the Framework Convention for the Protection of National Minorities (2 March 2006).

45 E.g. Article 6(1).

46 Article 14(3), cf Article 5(2).

47 ACFC, Commentary No 1 (n 44) 10-11.

48 Ibid 15 .

49 Ibid 9.

50 E.g. Gudmunder Alfredsson, 'A Frame for an Incomplete Painting: Comparison of the Framework Convention for the Protection of National Minorities with International Standards and Monitoring Procedures' (2000) 7 International Journal on Minority and Group Rights 291. 
undermines minority rights, demonstrating considerable flexibility in its approach. It is argued that the key here is the balancing of unity in diversity, and the shifting of priorities in response to changing circumstances and contexts. In developing its approach, the ACFC has notably been able to draw upon the experiences of the Organization for Security and Co-operation in Europe (OSCE) High Commissioner on National Minorities (HCNM), ${ }^{51}$ whose mandate is focused on conflict-prevention and who has therefore paid considerable attention to the balancing of unity and diversity in a range of deeply divided and post-conflict societies. ${ }^{52}$ Indeed, it is the HCNM which has taken the lead in developing an approach to integration which is aimed at strengthening rather than undermining minority rights. ${ }^{53}$ Its approach is therefore the focus of the next section.

\section{Unity in diversity: the approach of the HCNM}

To what extent is the promotion of integration seen as necessary to protect against segregation in societies at risk of conflict? And is there a way of promoting integration that does not undermine or restrict minority rights? As will be seen, the ACFC has been increasingly addressing these questions in the context of the Western Balkans and has explicitly stated in its Commentary on Education that in countries that have experienced conflict or are experiencing interethnic tension or aggressive nationalism, the need to ensure contact, dialogue and integration is a compelling priority'. ${ }^{54}$ Like the ACFC, the HCNM has produced a range of thematic guidelines promoting good practice and based on the relevant European and international standards. Given the conflict-prevention aspect of the HCNM's mandate, these thematic guidelines are more tailored to the situations considered within this article and demonstrate a notable shift over the years away from separation and towards more integrated approaches.

The Hague Recommendations Regarding the Education Rights of National Minorities were the first to be adopted ${ }^{55}$ and emphasised the importance of acquiring proper knowledge of both the mother tongue and the state language. They included extensive provisions in relation to minority language education at primary and second level, as well as teacher training, vocational training and higher education. It was noted, for example, that educational research indicated that education at the lower levels should 'ideally' be in the minority language, with a substantial part of the curriculum taught through the minority language at secondary level. ${ }^{56}$ The need for intercultural as well as multicultural education was meanwhile particularly emphasised in relation to the compulsory curriculum, which was to include 'the teaching of the histories, cultures and traditions of their respective national minorities'. ${ }^{57}$

Over time, and in light of the HCNM's experiences, greater emphasis has been placed on the dangers of separation and the advantages of integration. ${ }^{58}$ This is illustrated particularly in the Ljubljana Guidelines on Integration adopted in 2012, which recognise that:

51 E.g. ACFC, Commentary No 1 (n 44); ACFC, Commentary No 2: The Effective Participation of Persons Belonging to National Minorities in Cultural, Social and Economic Life and in Public Affairs, 27 February 2008, and ACFC, Commentary No 3 (n 37).

The Office of HCNM was established by the CSCE Helsinki Document 1993: The Challenges of Change II.

53 Pentikeinen (n 30) 39.

54 ACFC, Commentary No 1 (n 44) 17.

55 October 1996.

56 Hague Recommendations nos 11-14.

57 Ibid no 19.

58 E.g. The Bolzano/Bozen Recommendations on National Minorities in Inter-State Relations and Explanatory Note, June 2008, 15. 
Integration is a dynamic, multi-actor process of mutual engagement that facilitates effective participation by all members of a diverse society in the economic, political, social and cultural life, and fosters a shared and inclusive sense of belonging at national and local levels. To support the integration process, States should adopt policies that aim to create a society in which diversity is respected and everyone, including all members of ethnic, linguistic, cultural or religious groups, contributes to building and maintaining a common and inclusive civic identity . . .59

Significantly, this approach is based on the recognition both that distinct identities can coexist in the public sphere ${ }^{60}$ and that identities can be 'multiple, multilayered, contextual and dynamic'. ${ }^{61}$ It has also been noted that it marks a shift from balancing integration and minority rights to a greater focus on the rights and responsibilities of all members of society. ${ }^{62}$ According to the Guidelines, the process of integration 'can lead to changes in majority and minority cultures', with the HCNM tending to speak 'about the integration of multi-ethnic societies rather than integration of a minority group into a particular society. ${ }^{63}$ This avoids the danger of the concept of integration actually being used as a cover for assimilationist policies. It is also recognised that the right balance will vary according to the situation and that it will change over time. ${ }^{64}$ The tension between minority rights and social cohesion is meanwhile explicitly recognised in principle 7 , which states that 'isolation or excessive separation may weaken cross-community links and undermine the cohesiveness of society'.

In relation to education, the Guidelines recognise the need to complement minority language education:

. . . by developing integrated and multilingual education systems at all levels designed to provide equal access, opportunities and educational opportunities, regardless of their majority or minority background. Such integrated education should also include teaching all pupils about the diversity in their society. ${ }^{65}$

Segregation meanwhile, even if 'self-induced by minority communities' is to be avoided. ${ }^{66}$ There is therefore a strong steer away from separation in these latest guidelines. For example, they recommend that:

Where appropriate, and based on demonstrated evidence, authorities should intervene to counter excessive separation and risks of segregation; for example, by establishing integrated school curricula ... Such policies should not unduly interfere with the respect for identity-related traditions and life styles, as provided for in minority rights. (emphasis added) ${ }^{67}$

59 The Ljubljana Guidelines on Integration of Diverse Societies, November 2012, 3-4.

60 Ibid principle 8.

61 Ibid principle 5.

62 Pentikeinen (n 30) 30.

63 Ljubljana Guidelines (n 59) 4. Similarly, the ACFC has made it clear that integration is distinct from assimilation and understood to involve both minority and majority contributions in a two-way process, which is 'a process of social cohesion that respectfully accommodates diversity while promoting a positive sense of belonging for all members of society' and will often lead to cultural change. ACFC, Commentary No 3 (n 51) para 25.

64 Ljubljana Guidelines (n 59) 17.

65 Ibid principle 45.

66 Ibid 56.

67 Ibid 17. 
The important role played by politicians and the private sector is also highlighted. ${ }^{68}$ Whilst the right to establish minority schools in accordance with parental wishes is still recognised as being of the utmost importance, it is also clear that when schools are established 'on the basis of culture, language or religion', whether by the state or privately, then the state is required to promote 'arrangements for promoting understanding and regular interaction between students'. ${ }^{69}$ The next two sections consider how this works out in practice in the context of the Western Balkans.

\section{Challenging segregation in $\mathrm{BiH}$}

The discussion above suggests that minority rights standards are sufficiently flexible to serve both accommodationist and integrationist ends, and that the inherent flexibility in the system can be used to promote integration in situations where there remains a risk of conflict between groups. There is increasing international interest in the development of integrated education in both $\mathrm{BiH}$ and the FYROM,${ }^{70}$ understood for the purposes of this section to refer to the 'deliberate coeducation of children who are normally educated apart in conflicted societies' ${ }^{71}$ It is clear that such initiatives have a key role to play in post-conflict societies, where segregation can be a real problem. This is particularly the case in Eastern and central Bosnia, home to many post-war returnees. ${ }^{72} \mathrm{It}$ is here that we see particular prominence of the 'two schools under one roof' phenomenon, which has been a matter of such concern for the international human rights community. ${ }^{73}$

According to the HCNM, 'when education [is] forgotten in peace agreements, postconflict countries struggle with new divisions and divisive narratives' ${ }^{74}$ It is therefore significant that education does not feature prominently in the Dayton accords, ${ }^{75}$ a fact which has been described by Torsti as 'a historical mistake' by the international community. ${ }^{76}$ As a result, decisions on education were made by the Republika Srpska (with a large Serb majority) and by the cantons within the Federation of Bosnia and Herzegovina, resulting in three different systems emerging. ${ }^{77}$ The 'two schools under one roof' policy was initially developed in $\mathrm{BiH}$ to accommodate returnee children, who constituted a minority in municipalities with a mixed Bosniac/Croat population in the Federation of $\mathrm{BiH} .{ }^{78}$ With two

68 Ibid principles 27 and 28.

69 Ibid 56.

70 E.g. Biljana Krstevska-Papic and Veton Zekolli, 'Integrated Education in the Republic of Macedonia' in Claire McGlynn, Michalinos Zembylas and Zvi Bekerman (eds), Integrated Education in Conflicted Societies (Palgrave Macmillan 2016) 135-46; Ljuljjeta Goranci-Brkic, 'Interethnic Dialogue and Cooperation for Integrated Education in BiH: The Practice and Experience of the Nansen Dialogue Center Sarajevo' in ibid, 59-68.

71 Michalinos Zembylas and Zvi Bekerman, 'General Conclusion: The Future of Integrated Education in Divided Societies' in McGlynn et al (n 70) 266.

72 Goranci-Brkic (n 70) 60-1.

73 E.g. UNCRC, 'Concluding Observations: Bosnia and Herzegovina' CRC/C/15/Add.260 (21 September 2005) paras 56-9; CESCR, 'Concluding Observations: Bosnia and Herzegovina' E/C12/BIH/CO/1 (24 January 2006); Committee on the Elimination of Racial Discrimination (CERD), 'Concluding Observations: Bosnia and Herzegovina' CERD/C/BIH/CO/7-8 (23 September 2010) para 11; CERD, 'Concluding Observations: Bosnia and Herzegovina’ CERD/C/BIH/CO/7-8 (23 September 2010) para 11; CERD, 'Concluding Observations: Bosnia and Herzegovina' CERD/C/BIH/CO/9-11 (12 June 2015) para 11.

74 HCNM (@oscehcnm)20 April 2016,13:23 \#thehague20.

75 The right to education is listed in both Article II of the Constitution in Annex 4 and in Article 1 of Annex 6.

76 Pilvi Torsti, 'Segregated Education and Texts: A Challenge to Peace in Bosnia and Herzegovina' (2009) 26 International Journal on World Peace 65, 70.

77 Ibid 67.

78 'Report of the Special Rapporteur in the Field of Cultural Rights, Farida Shaheed: Mission to Bosnia and Herzegovina' A/HRC/25/49/Add 1 (3 March 2014) paras 38-9. 
schools located in one building, children from the two groups are taught separately under different administrations and with different teaching staff and curricula. ${ }^{79}$ Although work has been ongoing on the development of integrated education in $\mathrm{BiH}$ (initially linked to an OSCE initiative) since $2002,{ }^{80}$ progress has been slow. Reported challenges have included 'fear and passivity of parents' and the lack of support amongst political elites. ${ }^{81}$ Meanwhile, the approach of the OSCE to educational initiatives in $\mathrm{BiH}$ in the early days has itself been criticised, with problems noted in relation to monitoring and implementation as well as expertise. $^{82}$

The key to the Dayton Peace Accords was the development of power-sharing between the three constituent peoples, or nations, with smaller minority groups unrepresented during most of the negotiations. ${ }^{83}$ It is therefore perhaps unsurprising that minority rights are addressed only in passing. ${ }^{84}$ However, one commentator has described Dayton as a 'missed opportunity' creatively to apply a multicultural model, balancing rights of individual citizens with rights of the various groups. ${ }^{85}$ A key question that emerged fairly early on was the extent to which constituent peoples could also benefit from the protection of European minority rights standards. The ACFC has been extremely flexible in its approach to this issue and considers that Bosniacs and Croats in the Republika Srpska and Serbs in the Federation of $\mathrm{BiH}$ should be able to rely on protection under the FCPNM should they wish to do so in relation to issues coming within the jurisdiction of the entities. ${ }^{86}$ The key for the ACFC was that the status of constituent peoples applied across the whole territory, regardless of whether the members were in a de facto majority or minority situation. ${ }^{87}$ Its view was that ensuring their protection as national minorities under the FCPNM 'would by no means imply a weakening of their status as constituent peoples ... but merely aim at offering an additional tool to respond to a specific need for protection'. ${ }^{88}$ This position was re-affirmed in the second reporting cycle, when it was noted that discussions with relevant representatives suggested members of these groups would not object to having access to this additional protection. ${ }^{89}$ This is a classic example of a situation where the flexibility of the FCPNM (in this case the lack of a definition of the term national minority) has been used to good effect by the ACFC and in way that strengthens rather than undermines minority rights.

79 A D Tveit, D L Cameron and V B Kovač, “Two Schools under one Roof” in Bosnia and Herzegovina: Exploring the Challenges of Group Identity and Deliberative Values among Bosniak and Croat Students' (2014) 66 International Journal of Educational Research 103, 104.

80 Goranci-Brkic (n 70) 61.

81 Ibid 62-3.

82 Torsti (n 76) 73-4.

83 James C O'Brien, 'The Dayton Agreement in Bosnia: Durable Cease-Fire, Permanent Negotiation' in W I Zartman and V Kremenyuk (eds), Peace versus Justice: Negotiating Forward-and Backward-Looking Outcomes (Rowman \& Littlefield 2005) 105.

84 The FCPNM is listed as one of 16 human rights treaties to be applied in an Appendix to the Agreement on Human Rights (Annex 6). There is also a reference to the protection of minority populations in Article 1 of the Agreement on the Rights of Refugees and Displaced Persons (Annex 7).

85 Tibor Várady, 'On the Chances of Ethnocultural Justice in East Central Europe' in Will Kymlicka and Magda Opalski (eds), Can Liberal Pluralism be Exported? Western Political Theory and Ethnic Relations in Eastern Europe (OUP 2001) 144-7.

86 ACFC 'Opinion on Bosnia and Herzegovina adopted on 27 May 2004' ACFC/INF/OP/I(2005)003, para 28. Cf UN Human Rights Committee, Ballantyne, Davidson, McIntyre v Canada, Communication Nos 359/1989 and 385/1989, UN Doc CCPR/C/47/D/359/1989 and 385/1989/Rev1 (1993), para 11.2 in relation to Article 27 of the International Covenant on Civil and Political Rights 1966. See also ACFC, Commentary No 4 (n 37).

87 Ibid para 26.

88 Ibid para 28.

89 ACFC 'Opinion on Bosnia and Herzegovina adopted on 9 October 2008' ACFC/INF/OP/II(2008)005, para 40. 
In relation to education, the early view of the ACFC was that the principles enshrined in Article 12(2) were 'of central importance' in the context of $\mathrm{BiH}$, describing it as 'crucial to eliminate elements of segregation' in the education system. ${ }^{90}$ These included separate entrances within the same buildings, ${ }^{91}$ as well as separate classes for Croat and Bosniac pupils. ${ }^{92}$ In doing so, the ACFC implicitly rejected the argument from Croat officials that a separate school system was needed to avoid assimilation. ${ }^{93}$ It further identified an urgent need for the numerous entities responsible for educational matters to coordinate their efforts. ${ }^{94}$ The ACFC also found that measures to foster knowledge and history of national minorities other than the three constituent peoples were insufficient, emphasising the need to educate the people about the 'multicultural character' of $\mathrm{BiH} .{ }^{95}$ It is clear that this is a particular problem in post-conflict societies, where the focus tends to be on relations between those on different sides of the conflict, with smaller minorities often neglected. Meanwhile, on a more positive note, moves towards the adoption of a common core curriculum to operate alongside a 'national group of subjects', 96 as well as the work of the Textbook Review Commission and the development of guidelines for history and geography textbooks, were also noted. ${ }^{97}$

What was particularly noteworthy from the second monitoring cycle was how little had changed, not just in relation to integration but also in relation to the development of minority language education. This was despite various legislative developments in relation to the rights of smaller national minorities, ${ }^{98}$ with the ACFC noting in particular the low visibility of such groups and their cultures and languages. ${ }^{99}$ In the educational sphere this was manifest in their almost complete absence from school syllabuses and textbooks ${ }^{100}$ and no teaching in the languages of those groups protected under the State Law on National Minorities. ${ }^{101}$ Indeed, even the teaching of minority languages at schools was described as 'very rare'. ${ }^{102}$ This can be linked to the separate issues of a shortage of appropriate educational material and of a sufficient number of trained teachers. ${ }^{103}$ This state of affairs also highlights the gap between the law and implementation, with problems arising despite provision for the inclusion of information about the history and culture of national minorities in the curricula ${ }^{104}$ and the provision of resources for the teaching of minority languages and for teacher training envisaged in the State Law on National Minorities, as amended in 2005. ${ }^{105}$ Meanwhile, during the third monitoring cycle, the ACFC expressed concern about the failure of the authorities to take a proactive approach in relation to the further development of minority language education

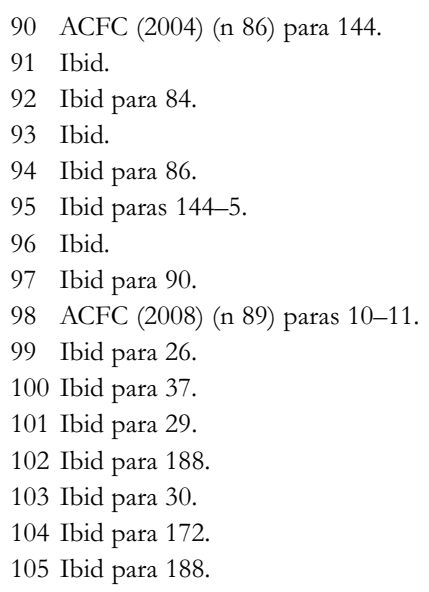


and criticised the continued invisibility of these languages. ${ }^{106}$ The state's ratification of the European Charter for Regional or Minority Languages appears to have made little difference in this regard. 107

It was, however, in relation to the continued segregation of education that the most significant concerns were raised, with a lack of political will to move towards further integration identified as a key obstacle. ${ }^{108}$ The state had been asked to provide information on progress towards a more integrated approach, and its response was that problems had arisen because responsibility in the Federation lay with the cantons. ${ }^{109}$ Meanwhile the ACFC's concerns focused not just on the 'two schools under one roof' phenomenon, but also on the continued establishment of mono-ethnic schools, often with the support of kin-states, as well as on obstacles to the implementation of the core curriculum. ${ }^{110}$ It noted in particular that limited powers of state-level authorities, given the spread of responsibilities at state, entity and cantonal levels, had led to a lack of coordination and oversight. ${ }^{111}$ The ACFC therefore urged the authorities to take far more determined measures to end segregation . . . and to impose more widespread application of the common core curricula'. ${ }^{112}$ This was reinforced by the Committee of Ministers, which stressed the need to 'take resolute steps to counteract the worrying trend towards increased school segregation of pupils along ethnic lines'. ${ }^{113}$ This is in step with the general approach of the Committee of Ministers to support and give political backup to the ACFC's recommendations rather than undermining its attempts, as was originally feared. ${ }^{114}$

During the third cycle, there was again considerable emphasis placed on the need to accelerate progress on abolishing 'two schools under one roof' and to replace it with a more integrated system and again avoiding the further development of mono-ethnic schools in mixed areas. ${ }^{115}$ This time the language used by the Committee of Ministers was even stronger, identifying the issue as one for immediate action and calling on the state to 'take as a matter of priority all necessary steps to eliminate segregation in education'. 116 The extension of the common core curriculum to all schools and to subjects such as history, geography and religion was also included in the call for immediate action. ${ }^{117}$ Furthermore, the state was asked to consider the impact of support from abroad in relation to segregation in education under Article 17 of the FCPNM, despite its

106 ACFC, 'Third Opinion on Bosnia and Herzegovina adopted on 7 March 2013' ACFC/INF/OP/III(2013)003, paras 142 and 144.

107 Council of Europe Treaty No 148, 5 November 1992. Instrument of ratification deposited 21 September 2010.

108 ACFC (2008) (n 89) para 170.

109 ACFC, 'Second Report Submitted by Bosnia and Herzegovina Pursuant to Article 25, Paragraph 1 of the Framework Convention for the Protection of National Minorities' (2 August 2007) ACFC/SR/II(2007)005, $34-5$.

110 ACFC (2008) (n 89) para 170.

111 Ibid para 171.

112 Ibid para 173.

113 Resolution CM/ResCMN(2009)6 on the implementation of the Framework Convention for the Protection of National Minorities by Bosnia and Herzegovina, adopted by the Committee of Ministers on 9 December 2009.

114 Kyriaki Topidi, 'Articles 24-26' in Marc Weller (ed), The Rights of Minorities: A Commentary on the European Framework Convention for the Protection of National Minorities (OUP 2005) 585-6.

115 ACFC (2013) (n 106) 2.

116 Resolution CM/ResCMN(2015) 5 on the implementation of the Framework Convention for the Protection of National Minorities by Bosnia and Herzegovina, adopted by the Committee of Ministers on 12 May 2015.

117 Ibid. 
obligation under that provision not to interfere with the rights of minorities 'to establish and maintain free and peaceful contacts across frontiers'.118 The concern appears to have been that such support was in practice reinforcing divisions and potentially undermining the goal of promoting mutual understanding and tolerance. ${ }^{119}$

It appears therefore that ongoing segregation in education in $\mathrm{BiH}$ has been a matter of particular concern, with 'excessive fragmentation and politicization of the education system' presenting a number of challenges both for stakeholders and for the ACFC.120 According to the UN Special Rapporteur on the Right to Education, who visited $\mathrm{BiH}$ in 2007, education is "widely perceived as a political tool; in practice, the school becomes a sort of "cold war" zone where students become victims of the bitterness and stereotypes projected by adults'. ${ }^{121}$ This was manifest in a system whereby the majority within each canton tended to dominate, ${ }^{122}$ with school boards being controlled by political parties, despite prohibitions of political party involvement in schools. ${ }^{123}$ In 2012 there was a visit by another of the UN's thematic mechanisms, the Independent Expert on Minority Issues. Her conclusion was much the same, that mono-ethnic schools and the 'two schools under one roof' system were preventing integration. ${ }^{124}$ She also found that political and other actors were presenting segregation as necessary for the protection of group identities. ${ }^{125}$ Her overall verdict in relation to minority rights was that:

... ethnically biased political agendas and a prioritization of party and ethnic interests of all citizens has perpetuated a polarized and adversarial political environment which is not conducive to reform or the full protection and promotion of minority rights in practice. ${ }^{126}$

Meanwhile, the ending of segregation on the basis of ethnicity and the need for the implementation of a common core curriculum were also raised under the UN's Universal Periodic Review process, ${ }^{127}$ and by the UN Special Rapporteur in the Field of Cultural Rights, who visited $\mathrm{BiH}$ in May 2013. ${ }^{128}$

Like the Independent Expert on Minority Issues, the Special Rapporteur in the Field of Cultural Rights was able to devote considerable attention to the political context, noting a general lack of consensus between the two main entities on the future of the state and between political elites, linked to different narratives of the past. ${ }^{129}$ Her analysis adopted more of a sociological approach, arguing that the current framework, "which over-emphasizes national/ethnic and religious affiliations, has been used by some actors to pursue ethno-nationalistic agendas, to promote the notion of hermetically sealed

118 ACFC (2013) (n 106) para 225.

119 Ibid paras 183-4.

120 Report of the UN Special Rapporteur on the Right to Education: 'Vernor Muñoz: Mission to Bosnia and Herzegovina' A/HRC/8/10/Add 4 (27 May 2008) para 54.

121 Ibid para 72.

122 Ibid para 73.

123 Ibid para 74.

124 Report of the Independent Expert on Minority Issues, 'Rita Izsák: Mission to Bosnia and Herzegovina' A/HRC/22/49/Add 1 (31 December 2012) para 73.

125 Ibid para 98.

126 Ibid para 78.

127 'Report of the Working Group on the Universal Periodic Review: Bosnia and Herzegovina' A/HRC/28/17 (4 December 2014) para 107.140-147.

128 Special Rapporteur (n 78) para 104.

129 Ibid paras 7-8. 
communities and to conduct segregation policies'. ${ }^{130}$ One of the examples she provided was the emphasis on differences between the Bosnian, Croatian and Serbian languages, which, coupled with rhetoric on the right of each person to learn his or her mother tongue, is used to justify a segregated education system. ${ }^{131}$ She described this, perhaps unfairly, as a 'misrepresentation of cultural rights'. ${ }^{132}$ She also noted that a call from the Parliament of the Federation for measures to be taken to end the 'two schools under one roof' system, a two-year plan of the Ministry of Education ${ }^{133}$ and a ruling of the Mostar Municipal Court that the system as it was currently operating was both illegal and discriminatory, did not result in any significant changes being made. ${ }^{134}$ The Supreme Court within the Federation of $\mathrm{BiH}$ has subsequently affirmed the finding of the Municipal Court. ${ }^{135}$

These reports provide an indication of the challenges facing the ACFC in pushing for a more integrated approach. Whilst the ACFC has consistently challenged segregation in education in $\mathrm{BiH}$, it is clear that the process of integration remains a long way off the standards set in the Ljubljana Guidelines. The evidence suggests that progress will continue to be slow. For example, more schools are becoming administratively unified as a result of pressure from the international community and initiatives from within the Federation itself. ${ }^{136}$ However, having visited the Gymnasium in Mostar where two schools were operating under one roof but as one legal entity with a single administrative structure, the UN Special Rapporteur in the Field of Cultural Rights reported that integration was minimal in practice, with only one class held in common and two different curricula being applied. ${ }^{137}$ There have also been some symbolic initiatives such as a joint drawing exhibit and the creation of a joint 'peace garden' in one school. ${ }^{138}$ Another initiative has been the development of a manual on national minorities for schools with the support of the OSCE and minority group representatives. ${ }^{139}$ However, the Special Rapporteur found that nationalist ideologies continue to dominate 'the symbolic cultural landscape', manifest in the sphere of education in the teaching of history and literature in particular, and in the writing and evaluating of textbooks. ${ }^{140}$ Meanwhile over 50 schools still operate under the 'two schools under one roof' policy. ${ }^{141}$

\section{Balancing integration and minority rights: the example of education in the FYROM}

Whilst segregation in education is also a problem in the FYROM, the evidence in this section presents a more positive picture of what can be achieved using the European

130 Ibid para 22.

131 Ibid para 23.

132 Ibid para 37.

133 The adoption of a set of Recommendations for the Elimination of Segregation in Education by the coordinating body of Ministers of Education within the Federation had earlier been welcomed by the ACFC: ACFC (2013) (n 106) para 120.

134 Special Rapporteur (n 78) para 40.

135 Denis Dzidic, 'Bosnia Federation Rules against Ethnically-Divided Schools’ Balkan Insight (4 November 2014) $<$ www.balkaninsight.com/en/article/bosnian-federation-court-rules-against-school-discrimination>.

136 Special Rapporteur (n 78) para 38.

137 Ibid paras 47-8.

138 Ibid para 42.

139 ACFC (2013) (n 106) para 126.

140 Special Rapporteur (n 78) paras 59-69.

141 Rodolfo Toe, 'Bosnia's Segregated Schools Perpetuate Ethnic Divisions' Balkan Insight (15 July 2016) <www.balkaninsight.com/en/article/bosnia-s-segregated-schools-perpetuate-ethnic-divisions-07-15-2016>. 
minority protection framework. This has not meant that challenges have not arisen, but rather that more discernible progress has been made both in relation to the protection of minority rights in education and in the development of a more integrated approach. It might seem as if the position of the Albanian minority in the FYROM is more of a classical minority-majority situation, ${ }^{142}$ with the Albanian minority primarily located in the north-west (where they are the majority in a number of municipalities) and with strong links to a kin-state. ${ }^{143}$ However, this would be a controversial interpretation given that some Albanians have argued for recognition as a 'constituent nation' rather than as a 'minority', a term perceived by many Albanians to imply inferiority. ${ }^{144}$ Meanwhile education has provided a key battleground for contestations. Indeed, one commentator observed before the outbreak of the conflict in 2001 that the issue of minority education had 'come to symbolize the struggle for all minority rights in the state', with concerns amongst the majority of a link to 'radical Albanian nationalism and Great Albanian expansionist ideology'. ${ }^{145}$ It was therefore significant that the Ohrid Framework Agreement referred specifically to the preservation of the 'multi-ethnic character' of society (s 1.3) and included extensive provisions on the provision of instruction in 'community' languages at primary and secondary level (s 6.1), state funding for higher level education in those languages spoken by at least 20 per cent of the population (s 6.2) and positive discrimination in relation to minority enrolment in state universities (s 6.3). 146 This therefore already set the tone for a more positive approach.

A number of challenges to the development of a more integrated approach were identified even during the first monitoring cycle under the FCPNM, with the ACFC expressing its 'deep concern at the attitudes of intolerance' being played out in debates over the future of integrated education. ${ }^{147}$ For example, the ACFC noted the tensions that had arisen over the introduction of additional classes in Albanian in Macedonian schools and the functioning of ethnically mixed schools. ${ }^{148}$ This had resulted in 'open conflict, polarizing young people along ethnic lines' ${ }^{149}$ Despite condemnation by the authorities, the ACFC considered that the state could do more in explaining objectives and discussing ways to move forward. ${ }^{150}$ This appears to be a classic example of the securitisation of ethnic relations and of minority rights being played out in the sphere of education, with the majority at state level perceiving their own rights to be under threat. ${ }^{151}$ The ACFC also stressed that more resources were needed to facilitate the development of a more integrated approach to education and expressed concern about a lack of institutional capacity. 152

142 The Albanian, Turkish, Vlach, Serbian, Roma and Bosniac peoples are protected under the FCPNM according to the Declaration contained in a letter from the Minister of Foreign Affairs of the FYROM, dated 16 April 2004.

143 According to the 2002 census, 64 per cent of the population are Macedonian and 25 per cent ethnic Albanian: Sinisa Jakov Marusic, 'Macedonia Albanians Propose End to Census Logjam’ Balkan Insight (6 October 2014) $<$ www.balkaninsight.com/en/article/macedonia-albanians-propose-census-change>.

144 Ratner (n 8) 592.

145 Eleanor Pritchard, 'A University of their Own' Central Europe Review (19 June 2000) <www.ce-review.org/ $00 / 24$ /pritchard24.html>.

146 OSCE, Ohrid Framework Agreement (13 August 2001) <www.osce.org/skopje/100622>.

147 ACFC, 'Opinion on "the Former Yugoslav Republic of Macedonia" adopted on 27 May 2004' $\mathrm{ACFC} / \mathrm{INF} / \mathrm{OP} / \mathrm{I}(2005) 001$, para 74.

148 Ibid.

149 Ibid para 51.

150 Ibid.

151 Ibid.

152 Ibid 75. 
On the other hand, there appears to have been considerable progress made in relation to minority language education in the FYROM since the coming into force of the FCPNM. At the end of the first monitoring cycle, it had been suggested that additional measures were required to ensure better accommodation of needs for teaching in minority languages. ${ }^{153}$ It is therefore significant that a number of improvements were observed in relation to the promotion and protection of minorities during the next monitoring cycle. For example, the ACFC noted that there had been some positive efforts in relation to the provision of education in minority languages, including with regard to textbooks, teacher training and improvement of facilities. ${ }^{154}$ This rather more positive state of affairs resulted in the Committee of Ministers noting the 'commendable measures' taken to improve implementation of the FCPNM and increased opportunities and initiatives taken in relation to the Albanian, Turkish, Serbian and Bosnian languages. ${ }^{155}$ There were, however, a number of outstanding issues. These included decentralisation of responsibilities in the sphere of education, which appeared to have caused particular problems for smaller communities. ${ }^{156}$ Meanwhile, it was noted that no progress had been made in relation to the anomaly whereby there is no right in the FYROM to establish private primary schools 157 and there were still concerns about opportunities for minority language education for smaller groups. ${ }^{158}$ As is often the case in post-conflict societies, there is a tendency to focus on the two (or three) largest, or most high profile, groups (in this case the Macedonian and Albanian communities) within textbooks and the wider curriculum, with the needs of smaller minorities somewhat neglected. ${ }^{159}$ The Committee of Ministers at the end of the cycle subsequently recommended the further expansion of opportunities for teaching of or in minority languages for smaller communities 'taking into account their real needs'. ${ }^{160}$ During the third monitoring cycle under the FCPNM, there were a number of further signs of improvement. ${ }^{161}$ This led to the overall finding of the ACFC in relation to minority language education that 'a well-developed system of minority language teaching' now exists. ${ }^{162}$ There was, notably, no change in relation to the right to establish private primary schools, which affects all communities. ${ }^{163}$

As the provision of minority language education has improved, so concerns about intercultural education have increased, particularly in relation to the development of interactions between Albanian and Macedonian children. ${ }^{164}$ This is another advantage of

153 Resolution CM/ResCMN(2005)4 on the implementation of the Framework Convention for the Protection of National Minorities by the 'Former Yugoslav Republic of Macedonia', adopted by the Committee of Ministers on 15 June 2005.

154 ACFC, 'Second Opinion on "the former Yugoslav Republic of Macedonia" adopted on 23 February 2007' ACFC/INF/OP/II(2007)002 paras 150-2. See also paras 173 and 180-3.

155 Resolution CM/ResCMN(2008)6 on the implementation of the Framework Convention for the Protection of National Minorities by 'the Former Yugoslav Republic of Macedonia' adopted by the Committee of Ministers on 9 July 2008.

156 ACFC (2007) (n 154) 154 and 157.

157 Ibid paras $174-5$.

158 Ibid paras 184-6.

159 Ibid para 144.

$160 \mathrm{CM} / \operatorname{Res}$ (n 155).

161 ACFC, 'Third Opinion on "the Former Yugoslav Republic of Macedonia” Adopted on 30 March 2011' ACFC/OP/III(2011)001, para 156.

162 Ibid para 154.

163 Ibid paras 149-51.

164 ACFC (2007) (n 154) para 142. 
the comprehensive approach of the ACFC and the flexibility that allows for a shifting of priorities over time. It also reflects increasing international concern about this issue, as discussed previously in relation to the Ljubljana Guidelines. The ACFC has, however, noted some positive developments. For example, during the second monitoring cycle, it was acknowledged that relations between the two communities had improved within society as a whole. ${ }^{165}$ Specifically, in relation to education, it appeared that tensions around the introduction of Albanian language classes in Macedonian schools had eased, with the role of civil society initiatives specifically highlighted. ${ }^{166}$ Meanwhile the numbers of Albanian and Macedonian children interested in studying the language in mixed municipalities had increased. ${ }^{167}$

Despite the progress that had been made, the ACFC found that society remained polarised, with 'sustained efforts' and the 'de-politicisation' of ethnic issues and political debate identified as the best ways forward. ${ }^{168}$ Similar to the criticisms of the 'two schools under one proof' policy in BiH discussed above, the ACFC expressed particular concern that children attending the same school were often taught separately and in separate premises. ${ }^{169}$ Whilst this can be seen as a way of ensuring that obligations are met in relation to the provision of minority language teaching, it leads to segregation in practice and the ACFC therefore encouraged the state to promote alternatives such as bilingual education. ${ }^{170}$ The important role played by civil society in promoting integration and reconciliation was again noted, ${ }^{171}$ with the state encouraged to increase its involvement and support. ${ }^{172}$ The Committee of Ministers meanwhile stressed that there was still a need for 'resolute efforts . . . to strengthen inter-ethnic dialogue' between children and teachers and in areas where those in the majority were de facto a minority. ${ }^{173}$

Progress in the lead-up to the third monitoring cycle was more disappointing. For example, the ACFC expressed regret that so little had changed in relation to opportunities for interactions between Albanian and Macedonian children and the fact that textbooks remained unbalanced from a minority protection perspective. ${ }^{174}$ This was despite significant investment by external actors, including the OSCE, in the development of a strategy on integrated education, with a lack of resources identified as a particular problem. ${ }^{175}$ It is therefore fairly unsurprising that the Committee of Ministers at the end of the third reporting cycle identified the continued polarisation of society along ethnic lines and the lack of significant interaction, including in education, as issues that remained of concern. It called furthermore for 'immediate action' in creating 'opportunities for interethnic dialogue in all spheres of life, in particular aiming to involve in joint activities

165 Ibid para 79.

166 Ibid para 152.

167 Ibid para 181.

168 Ibid para 83 .

169 Ibid para 142.

170 Ibid para 143.

171 Note in particular the work of the Nansen Dialogue Centre Skopje discussed by Krstevska-Papic and Zekolli (n 70).

172 ACFC (2007) (n 154) para 147.

$173 \mathrm{CM} / \operatorname{Res}(\mathrm{n} 155)$.

174 ACFC (2011) (n 161) para 130

175 Ibid paras 131-4. 
children and young people living in ethnically-mixed areas'. ${ }^{176}$ The issue was therefore identified as one to be prioritised and with immediate effect.

It is clear that ethnic relations remain highly politicised in the FYROM more than 15 years after the end of the conflict. This is not helped by the lack of interaction between the two main groups, which has only served to reinforce the development of parallel societies and structures. ${ }^{177}$ Meanwhile contestation over education continues to arise, with controversies during the third monitoring cycle over the decision to introduce Macedonian language teaching from the first year of education without adequate consultation with relevant stakeholders. This led to protests and the eventual revoking of the decision. ${ }^{178}$ Other challenges noted by researchers on integrated education include gaining the confidence of parents in a context where a decision to send a child to an integrated school could be seen as a betrayal and obtaining the support of political elites. ${ }^{179}$

The importance of looking at what is happening at grassroots level and within domestic social institutions has been recognised as key to the effective implementation of human rights. ${ }^{180}$ What is particularly evident in relation to the FYROM is the efforts being made both by the government and by civil society with the support of the wider international community. The HCNM continues to engage in both $\mathrm{BiH}$ and the FYROM, visiting the latter twice during the political crisis in 2015 and warning against the crisis being used to inflame ethnic tensions. ${ }^{181}$ Unsurprisingly, in light of the discussion above, a key focus in relation to education has been the promotion of the Ljubljana Guidelines and on societal integration, with a particular emphasis on bilingual and multilingual education, integrated education and teaching of state languages. ${ }^{182}$ Meanwhile the OSCE Mission to the FYROM has been providing more practical support, as well as facilitating a governmental review of the Ohrid Agreement. It has also been helping to review the implementation of the Law on Communities, which protects minority rights, and supporting implementation of the Government's Strategy towards Integrated Education. ${ }^{183}$ The FYROM has been a candidate country for EU membership since 2005. ${ }^{184}$ In its latest progress report, the EU Commission picked up on a number of the issues discussed in this article, noting that the 'inter-ethnic situation remains fragile'185 and that planned reforms had been put on hold because of the public protests in 2015.186 It also found that measures to promote integration were insufficient and that multiple forms of discrimination were persisting. ${ }^{187}$ As evident from the discussion so far, the ACFC does not work in isolation and there is a complementarity in the approach of the

176 Resolution CM/ResCMN(2012)13 on the implementation of the Framework Convention for the Protection of National Minorities by 'the Former Yugoslav Republic of Macedonia' adopted by the Committee of Ministers on 4 July 2012.

177 ACFC (2011) (n 161) para 82.

178 Ibid para 157. The ACFC's Fourth Opinion on the FYROM is due to be made public in late 2016.

179 Krstevska-Papic and Zekolli (n 70) 139-40.

180 Tom Zwart 'Using Local Culture to Further the Implementation of International Human Rights: The Receptor Approach' (2012) 34 Human Rights Quarterly 546.

181 OSCE Annual Report (2015) 8.

182 OSCE Annual Report (2014) 50; OSCE Annual Report (2015) 49.

183 OSCE Annual Report (2014) 66-7; OSCE Annual Report (2015) 64-5. See also approach of the Mission in $\mathrm{BiH}$ - OSCE Annual Report (2014) 59; OSCE Annual Report (2015) 56.

$184 \mathrm{BiH}$ submitted its application to join on 15 February 2016.

185 European Commission, 'The Former Yugoslav Republic of Macedonia Report 2015' SWD(2015)212 (10 November 2015) 4.

186 Ibid 66.

187 Ibid 61. 
various bodies involved in monitoring progress and in calling for improvements to be made. The ACFC does nonetheless have a unique role to play as the only human rights treaty-body specifically focused on minority rights and minority protection issues. This enables the adoption of a comprehensive approach, with consideration of progress in realising minority rights alongside the development of more integrated approaches. This is supplemented by more practical support from the OSCE and by stronger political incentives for progress from the EU.

\section{Conclusion}

To what extent, then, has the European minority protection framework proved adaptable and able to respond to the challenges posed by continued segregation between groups previously involved in conflict in the Western Balkans? This article has argued that there is an inherent flexibility in the FCPNM, which should be considered as a particular strength of the European minority protection framework. The pragmatic approach adopted by the ACFC has enabled changing priorities over time and with reference to the longer-term impact of developments on the ground. This has led to the development of a strong challenge to the entrenchment of segregation in situations where polarisation between different ethnic groups remains unacceptably high. It is clear that demands for a more integrated approach to education and for integration to be prioritised are a necessity in the contexts of both $\mathrm{BiH}$ and the FYROM and serve to strengthen rather than undermine the European minority protection framework. Minority rights remain high on the agenda of the ACFC alongside integration and it is alert to the impact that any change in policy or perceived shift in the balance of power can have on relations between different ethnic groups. The case studies also identified a number of ongoing challenges in relation to implementation linked to the wider political contexts within which minority rights standards are realised. The limits of what European minority rights law can achieve when the future of education remains such a highly contested issue and when inter-ethnic relations remain fragile and highly politicised are all too evident. This does not mean that the minority rights project is doomed, as the case studies also reveal that some progress is being made, and that there are a lot of different factors in play. The work of human rights monitoring bodies is inevitably always a 'work in progress', with progression in one area often accompanied by regression in another. The FCPNM is only one cog in the wheel, although an important one given its uniqueness as the only multilateral treaty focused specifically on the protection of minorities and of minority rights as an integral part of the human rights framework. It therefore needs to work to ensure the continued monitoring of law, policy and practice and to help find a better balance between the claims of different ethnic groups and wider societal cohesion and integration than is currently the case in many post-conflict situations. 
